Article

\title{
Between Industrialism and Postindustrialism-the Case of Small Towns in a Large Urban Region: The Katowice Conurbation, Poland
}

\author{
Robert Krzysztofik *D, Iwona Kantor-Pietraga and Franciszek Kłosowski \\ Department of Economic Geography, University of Silesia in Katowice, 41-200 Sosnowiec, Poland \\ * Correspondence: robert_krzysztofik@interia.pl
}

Received: 2 June 2019; Accepted: 10 July 2019; Published: 12 July 2019

\begin{abstract}
The socio-economic transformation of (post)mining towns takes different forms and follows varied pathways. This obvious fact acquires a different significance in a region that is a polycentric urban conurbation whose growth was based on coal mining and industry. Particularly as concerns small towns, which are a minority in it in terms of numbers. This paper attempts to present the issue based on the cases of two small towns, Leedziny and Radzionków, located in the Katowice conurbation in southern Poland. While having similar mining origins, the towns currently represent two radically different paths of economic development. Both mentioned towns are developing relatively well. However, certain threats to their growth are also revealed: social functional, environmental and even political. A closer inspection of both is important in that the two small towns are examples of two extremities in the region, between which other types of towns undergoing socio-economic transformation are situated. The selected examples also indicate that a small (post)mining town does not necessarily have to be 'the place that don't matter'. Additionally, an important conclusion is that despite many objective barriers, a small town in a mining region can follow a line of development based on the industry 4.0 concept.
\end{abstract}

Keywords: postindustrial town; industrial town; socio-economic transformation; urban development; Poland

\section{Introduction}

Small towns in agricultural regions of Europe most often build their socio-economic potential on relationships formed with their own local hinterlands, which they, to a smaller or larger extent, attempt to supplement with specialized services, industrial or, less frequently, resort functions [1-3]. This is still dominant, particularly in Central and Eastern Europe; however, two other models accompany small-town development [4-6]. The first is a model of a small town with highly specialized mining or industrial functions [7-9]. The second model of development covers small towns with diversified functions, located in the neighborhoods of large metropolitan cities [10-12]. The rarest case, however, is towns whose model of development is based on specializations in mining and industry and a location within large urban complexes.

The polycentric Katowice conurbation in southern Poland is an example of a geographical region in which the development of small towns combines the last two of the abovementioned models. However, because of a singular model of polycentricism, integrating industrial functions and differing from the model most often discussed in the literature [13-15], the case of the Katowice conurbation should be seen as a comparatively original one in Central and Eastern Europe. Namely, settlements are plasma-type, most towns have from 30 to 285 thousand inhabitants, towns directly border each other, and urban infrastructure is uninterrupted. The analyzing region was subjected to socialist 
urbanization and industrialization, and it is divided by a historical and cultural boundary (Upper Silesia-Dabrowa Basin).

Irrespective of the position of small mining and industrial towns in the settlement system of a region like the Katowice conurbation, the key problem in studies from a contemporary perspective is the transformation of industrial and mining regions in general. There is an extensive body of work on this issue as well as established research trends:economic [16-18], geographical [19-21], sociological [22-24], spatial and infrastructural [25-27], and based on urban policy [28-32]. From another perspective, one that is important for examination of the titular Katowice conurbation, studies on the transformation of mining regions in Central and Eastern Europe are valuable. Additionally, they have a common denominator in the attribute of post-socialism to some extent. Here, work on the Czech Republic [33-35] and Donbas [36,37] should be pointed out. Meanwhile, the specific settlement form in the Katowice conurbation, a network of large and medium-sized towns that mostly border one another and have industrial and mining origins, prompts comparisons with the Ruhrregion in Germany [38-41]. The profusion of takes on (post)mining region transformation, on the one hand, and some originality of the key determinants of the Katowice conurbation's development, even compared to the abovementioned coal basins of Central Europe, on the other, presents a research challenge that is already at diagnosis level. In an attempt to capture the socio-economic changes in the region in question, some models with general explanations are, thus, useful, as are models developed specifically to describe the paths of changes in the Katowice conurbation.

Among the former, in the authors' belief, Phelps and Ozawa's [42] model undoubtedly plays a key role. Its dynamic approach to describing concepts in industrial and mining regions, such as proto-industrialization, industrialization, and postindustrialization, treated as stages of development, is a good reflection of Poland's situation. Of course, when the concept is applied to the Katowice conurbation, allowances must be made for differences. Namely, a transformation of regions that were previously based on industrial functions results in a diverse socio-economic situation of the towns located there. Apart from towns that benefit from the transformation, the settlement system also includes towns that lose their function, role, and position.

It is some of these that fall within the scope of the concept proposed by Rodriguez-Pose [43] of 'the places that don't matter'. This concept refers to a significantly broader trend of research on geographical, economic, and usually social peripheries, which underlines the dual paths of town functioning, both at the stage of stable development and in periods of transformation. In Poland, Kantor-Pietraga [44] proposed the category of 'functionally unnecessary' towns for those that meet the criterion of 'the places that don't matter'. These settlements lost their previous exogenous functions and did not evolve new ones; their functioning is based on commuting to other towns and on endogenous functions.

Both a town's 'insignificance' and its being 'functionally unnecessary' often result from the well-described phenomenon of low adaptability to change in monofunctional regions [45], and also from 'the weakness of strong ties' phenomenon described by Grabher [46], which emphasizes dependence on previous activities and low capacity for adapting to new ones. This problem has been studied for the titular Katowice conurbation among others by Gwosdz and Sobala-Gwosdz [47] and Gwosdz [48].

In Polish research, attempts to explain the transformation of the (post)industrial Katowice region have been made in at least three other dimensions: structuralist, systemic, and ontological. A structuralist approach, indicating the limits of capacity for sectoral transformation in this region's economy, was presented by Gwosdz [48]. An important message of Gwosdz's book is that the capacity of polycentric (post)mining and (post)industrial regions for changing their socio-economic character towards knowledge-based activities is hampered because of their path dependency. This trend also includes Tkocz's [49] work on the nature of paths of industry transformation in the discussed region.

A systemic approach to functional changes in the Katowice conurbation, meanwhile, was presented by Krzysztofik et al. [50]. The authors introduce the term 'transindustrialism' to indicate the heterogeneity of economic development paths of the conurbation's towns and the different directions 
and dynamics of sector changes in the economy. The authors explain that phenomena such as existence of traditional industry; deindustrialization and reindustrialization; development based on high-tech industry and industry 4.0; development of business process outsourcing (BPO), shared services centers (SSCs), and research and development (R\&D); and development based on traditional and highly-specialized services can apply to towns concentrated in a relatively small urban complex at one time. This is a natural stage of regional development, defined as transindustrialization.

The analysis by Krzysztofik [51] has a different ontological dimension. The process of contemporary changes in the Katowice region has been interpreted with respect to the operation of centrifugal forces as a key stimulator of the regional settlement system. In this case, centrifugal forces are identified with coal mining and industrial production, whose export from the Katowice conurbation is a model mechanism of economic influences described by the scientific metaphor of centrifugal forces.

Taking the theoretical explanations presented above as the background, in this paper the authors focus on the small towns in the region. As aforementioned, studies of such towns are something of a research gap, particularly in the context of the conceptual trends named above. It is not without significance that they may be described as 'an original category (demographical size) of towns in a specific (demographic size, functions, settlement system) region of Central and Eastern Europe'. The paper also demonstrates the specific nature of small industrial towns of the Katowice conurbation as compared to small towns with similar functions in other European countries.

However, for the authors, the case of the Katowice conurbation is not only an attempt to define the nature of a small (post)industrial town in a large urban region, it is also an attempt to define the real capacity for transformation of this type of town, with respect to complicated exogenous and endogenous determinants. The fulfilment of this objective was based on analyses of two of the region's small towns, Ledziny and Radzionków, which, despite identical functional and even historical origins, currently represent quite different paths of economic and partly also social development. The two towns' cases are discussed in the context of the most important phenomena of the Katowice conurbation's socio-economic transformation and its effects.

\section{Methodology}

The paper offers both explanations and a review. It was written on the basis of the collection of data, facts, and explanations largely proposed by the authors in prior publications $[50,52,53]$. These publications concerned the whole Katowice region. Using previous findings [52] and the presented updated indicators of social and economic development, this article focuses on showing the specific nature of small-town development. To this end, the rate of territorial development (RTD) indicator proposed by the Regionalne Centrum Analiz Strategicznych (Regional Centre for Strategic Analysis) of the Marshal Office in Katowice was also used. The indicator was calculated for the attributes of a modern economy. Measurement was based on set weights for each of the 36 variables considered. Due to limited availability of many data types, delimitation was made based on county units. They allowed differences within large and some of the mid-sized towns to be captured. In this paper, using study results obtained by Regionalne Centrum Analiz Strategicznych [54], the small towns of the region only set against the counties in which they were located were marked. Small towns were divided into three groups: industrial (including mining), postindustrial (in which key traditional industrial plants have been closed down), and those in which traditional industry had low significance prior to 1989.

The novelty in terms of methodology of research on postindustrialism of small (post)industrial towns is the authors' draft of models of economic transformations (in the next chapter). While they were designed for the Katowice region, they are characterized by a wider applicability to other world regions. However, the way of measuring functions is a challenge for the presented models. Due to gaps in sources and differences in determining size ranges for selected phenomena, the proposed typology of models may, in certain cases, be somewhat limited. 
Discovering the opinions of stakeholders of socio-economic and political life, both at the regional and the local level, was an important element of the research. The paper's authors were able acquaint themselves with the opinions of over 30 people through interviews, workshops, and, no less importantly, free conversation and comments. In view of the paper's subject and geographical location of the research, the personal interview held by the mayor of Radzionków was particularly important.

\section{Specific Features of the Katowice Conurbation's Economic Transformation}

In the Katowice region the industrial revolution brought about the dominance of industry, mainly coal mining, the iron industry, and machine construction. The result was the formation of a large, over $500 \mathrm{~km}$-wide urban core, formally divided into tens of towns and urbanized communes. In the 1960s and 1970s these units were integrated in the name of socialist central planning, which assumed the functioning of a very large industry and industrial and mining cities. This phenomenon was accompanied by rapid growth and modernization of both branches of the economy. The process of economic restructuring, which began at the end of the 20th century, contributed to a fall in the numbers of persons employed in industry and growth of those employed in services [53]. It also strengthened or instigated many other phenomena such as urban shrinkage, growth of unemployment, social problems appearing mainly in worker districts, and disintegration of administrative territory of the large cities created earlier $[51,55,56]$. In the 1990s, independent urban status was regained among others by the titular Lędziny (1991) and Radzionków (1998). The network of small (post)mining and (post)industrial towns in the province grew by eight restituted towns.

Above all, clear changes in the region's economic structure took place. In the Katowice conurbation (within the Górnoślaska-Zagłębiowska Metropolis) the share of employed in industry fell from $47.9 \%$ in 2000 to $37.7 \%$ in 2017, while the share in services rose from $51.6 \%$ to $62.1 \%$. The share of agriculture was marginal and dropped from $0.5 \%$ in 2000 to $0.2 \%$ in 2017 [57,58].

The Katowice conurbation is an example of a trend observed in Central and East Europe, and it is connected to a visible decline in persons employed in industry, particularly traditional industry [59]. Significant changes occurred in the very structure of industry, where primarily the role of mining shrank [49]. The number of employed in mining in the Katowice conurbation fell from around 280-300 thousand in the years 1989-1990 to around 47-50 thousand in 2018-2019 [49,60,61]. (Due to the lack of full data on employment, their unreliability in the socialist period, and structural and organizational changes within individual mines, only approximate values can be established for the area in question). The fall in employment in traditional industry, however, was accompanied by a rapid rise in numbers of employed in the automotive industry [62,63]. A significant role in the development of this branch was played by the Katowice Special Economic Zone, in which 350 new businesses, chiefly automotive companies, were located, and around 76 thousand new jobs were created [64], most of them within the Katowice conurbation. Despite significant structural changes, the region's limited innovativeness and the dynamics of development are still problems for the Silesian province, in which the conurbation in question is located [65]. However, the most visible feature is the diversified level of economic development between the cities and counties of the analyzed region. This also applies to attributes of 'the modern economy', which was defined in the research of the Regional Center for Strategic Analysis [54]. The difference is aptly portrayed in Figure 1. They also pertain to small towns. While in Figure 1 the differences have an indirect character (only differences between counties in which small towns are located are visible), they are a good point of reference with respect to opportunities for development and transformation of the small (post)industrial towns located there. Neighborhoods are no less important, which may be seen in the titular examples of Lędziny and Radzionków, which border on larger towns with diametrically different levels of the RTD indicator. 


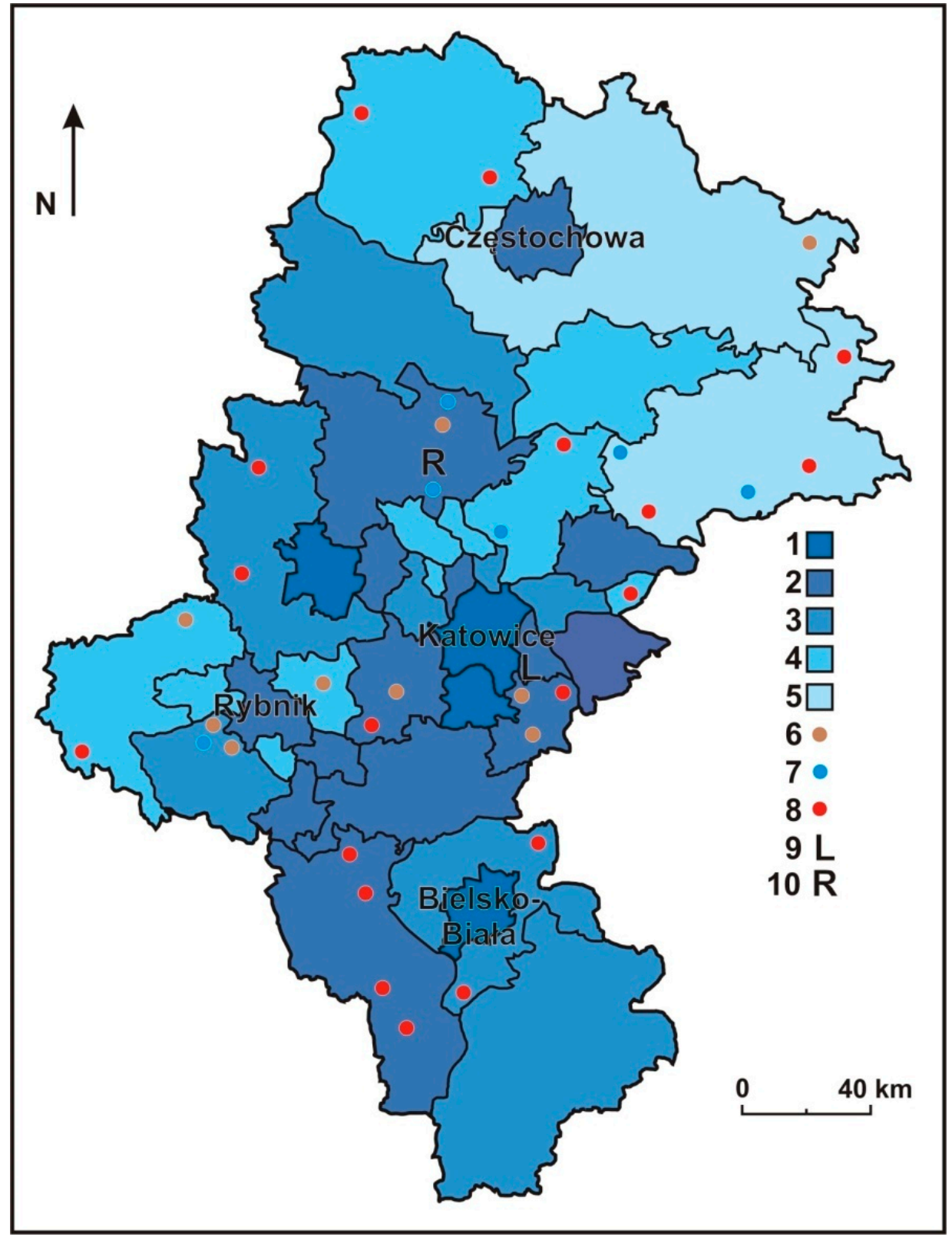

Figure 1. The rate of territorial development (RTD) for the attributes of The Modern Economy in Silesian province in 2012 (illustration sourced by [54] — the RTD rate and authors—types of towns). Explanations: The RDT rate: 1-very high; 2-high; 3-average; 4-low; and 5-very low; types of towns: 6-industrial towns; 7-postindustrial small towns; and 8-other small towns (service or residential functions before economic transformation; L-Lędziny; R-Radzionków.

As an economic region, the Katowice conurbation has plasma-like spatial and functional structures, in which the core is built mainly of towns with 50,000-200,000 inhabitants. This means that agglomeration advantages are theoretically evenly distributed within it. Nevertheless, differing town sizes, differing trajectories of economic development, as well as creativity of local stakeholders cause some differentiation, and leading centers of economic development alternate with towns with low indicators of modern economy and creative industry development. This is clearly visible in Figure 1. It is also indicated by the number of creative industry entities per 1000 people in the conurbation core. It varies from 4.0 entities in Zabrze to 15.6 in Katowice [66].

Great challenges also include infrastructural problems and intensive depopulation in over $90 \%$ of towns, including all the largest [67]. 
The development of the region's towns that had an industrial and mining character, even by the end of the 20th century, including small and medium-sized ones, varies distinctly. The paths of transformation reveal at least nine different models that refer to ideas of transindustrialism [50]. They are shown in Figure 2. Importantly, as of yet, no town has achieved an urban model which combines residential functions with high-tech service, creative industry or, on the other hand, industry 4.0 functions. The most popular model for dynamic functional transformation of previous mining and industrial towns is now industrial and service, mining and service, and mining and industrial centers.

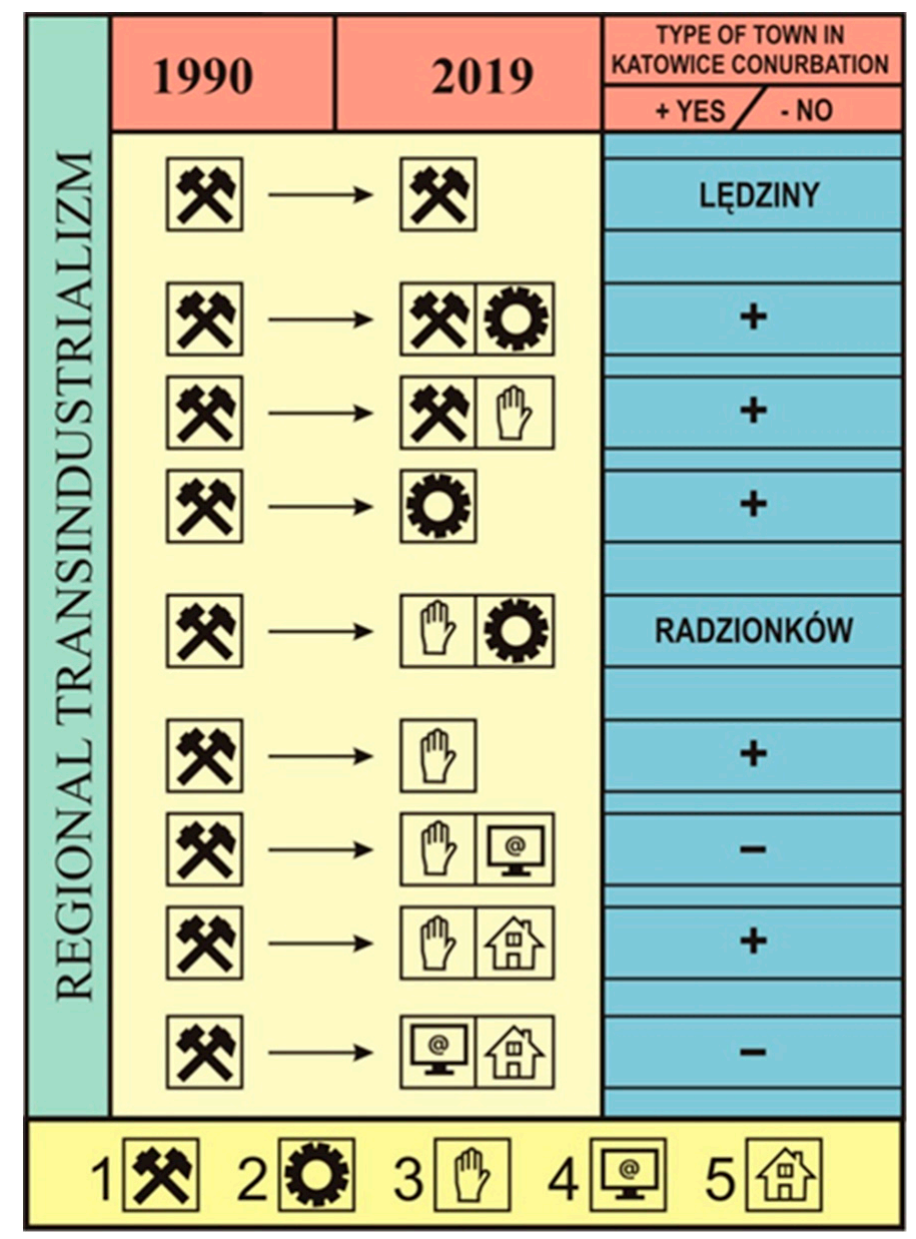

Figure 2. Models of economic transformation of the Katowice conurbation's towns as the core of the transindustrialism phenomenon (illustration sourced by authors). Explanations: 1-coal-mining; 2-industry; 3-service; 4-business process outsourcing (BPO), shared services centers (SSCs), research and development (R\&D), and industry 4.0; and 5-residential functions.

For a better understanding of functional differences between small towns of mining origins, the paper presents two settlements with quite divergent trajectories of change. The first is Ledziny-a town in the southeastern part of the conurbation. Its development is still based on mining, services, and to a slight degree on small manufacturing companies. The second is Radzionków in the northern part of the region. This town currently has service and industrial functions with no participation in mining (Figure 3). 


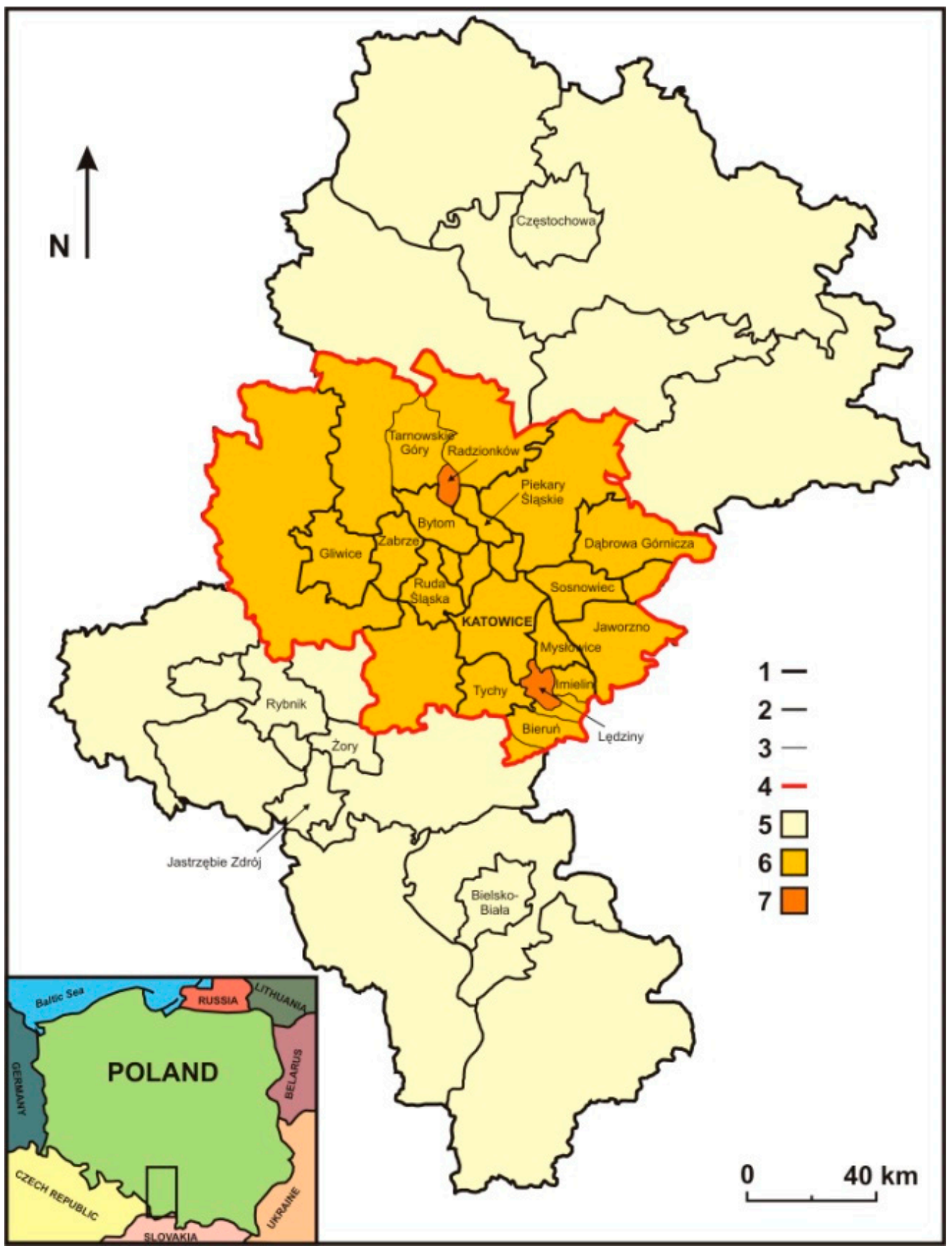

Figure 3. Leedziny and Radzionków on the map of the Silesian province and the Katowice conurbation (illustration sourced by authors). Explanations: 1-Silesian province boundary; 2-county boundaries; 3-commune boundaries; 4-Katowice conurbation boundaries; 5-area of the Silesian province outside the Katowice conurbation; 6-area of the Katowice conurbation; and 7-towns of Lędziny and Radzionków discussed in the paper.

\section{Lędziny and Radzionków—Similar Functional Origins, Different Present Development}

Until the 1990s, the economic history of Lędziny and Radzionków was very similar and characteristic of a larger number of today's small towns in the Katowice conurbation (including Bierun, Miasteczko Ślaskie, and Wojkowice). As a result of the discovery of coal seams or zinc and lead ores, or sometimes the building of a foundry or large production plant, a village or small town changed its functions from agricultural or commercial to industrial within a relatively short time. The case of Lędziny and Radzionków was no different. 
In Ledziny, the origins of mining go back to 1843-1845. In the postwar period mining was still being developed, as a result of which in 1952 the still existent 'Ziemowit' mine was put into operation (Figure 4). Meanwhile, the mine in Radzionków opened in 1877. Coal mining in the now-closed 'Radzionków' mine ceased in 1996 caused by exhaustion of the deposits (Figure 5). Thereby, the largest industrial plant and Radzionków's main 'provider' disappeared from its landscape. Of course, miners did not disappear from Radzionków, as a significant share found work in neighboring mines (particularly in Piekary Śląskie and Bytom).

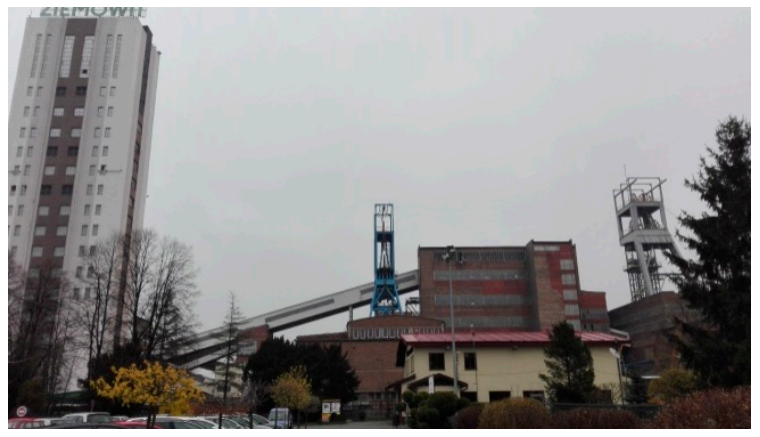

(a)

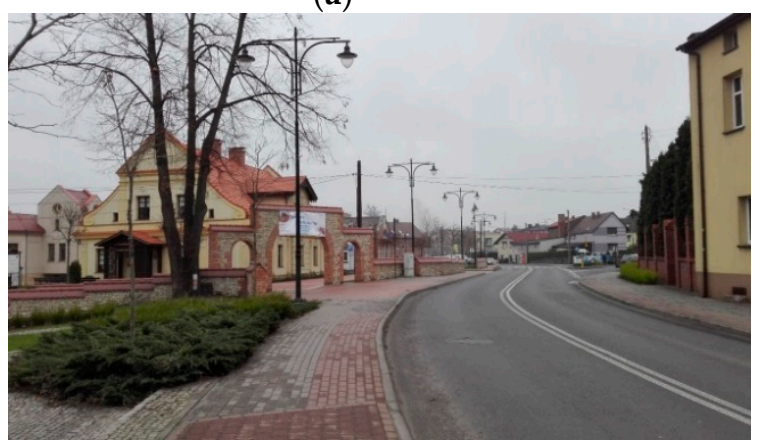

(c)

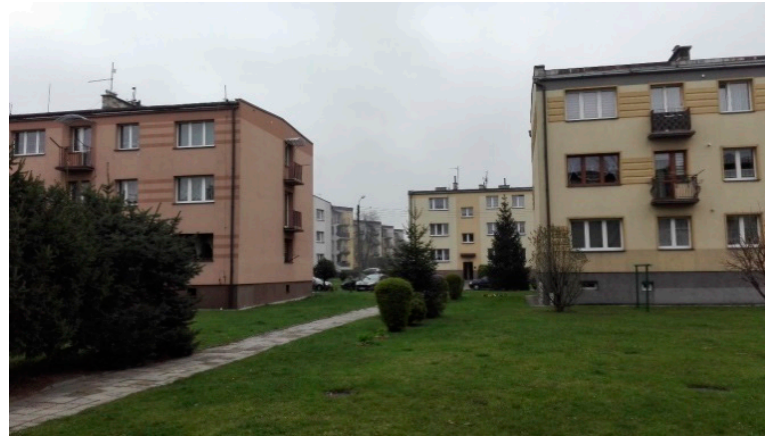

(b)

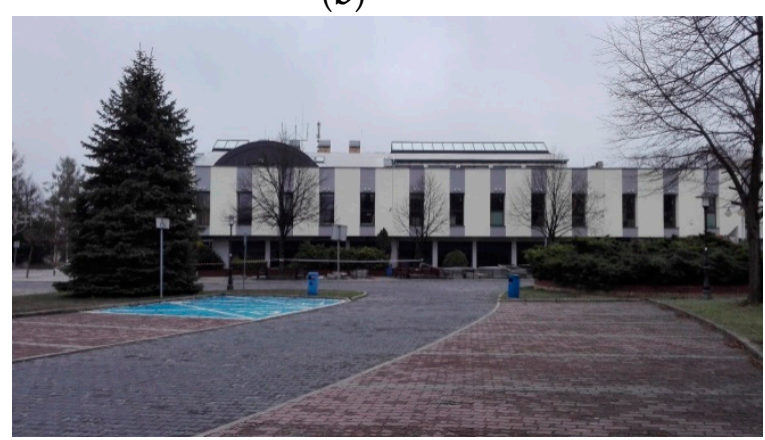

(d)

Figure 4. Lędziny: (a) coal mine, (b) postwar estate built for miners (revitalized), (c) low buildings in Lędziny, recalling the town's rural origins, and (d) Town Hall building (illustration sourced by authors).

The fate of mining in Ledziny was different [68]. As part of restructuring, in 2016 the local 'Ziemowit' mine was organizationally merged with the 'Piast' mine in neighboring Bierun and called 'Piast-Ziemowit'. In this period, the mine, with a good outlook for growth (available seams), became part of the largest mining company in Poland: Polska Grupa Górnicza.

In the second quarter of 2019, the Lędziny mine employed 3609 people [69], and the production capacity of its excavation face was $17,800 \mathrm{t} / \mathrm{d}$. 'Piast-Ziemowit' as a whole produces around 7 million tons of coal (i.e., 11\% of Polish coal production in 2018). According to current estimates, coal resources held by the mine will last at least until 2040 and, after the planned start of mining in new seams in the neighboring town of Imielin, even until the 2050s. However, due to resident protests, obtaining a mining concession for the Imielin region may not be an easy matter [70].

The existence of a large industrial plant employing over 3.5 thousand people in a small town (16 thousand inhabitants) results in a favorable labor market situation (Table 1), especially since the mine is the largest, but not the only, plant in the town (there are 77 other smaller industrial plants and a number of service establishments). The mine's function, and that of many other large industrial plants in neighboring towns, means that unemployment here has not exceeded $5 \%$ for many years. However, it should be noted that, due to strong monofunctionality, Ledziny residents are less economically active than Radzionków residents (Table 1). The authorities of Ledziny are aware of the consequences of being overly dependent on one large industrial plant and, thus, strive to support actions that increase residents' activity and to create dedicated zones for economic activity [71], for example, the construction 
of the large Goodman Ledziny Logistics Centre $\left(111,500 \mathrm{~m}^{2}\right)$. The strategy of the town highlighted also that 'The significance of the mine in Ledziny's economy does not preclude [it] from being open to investments in other sectors' [71].

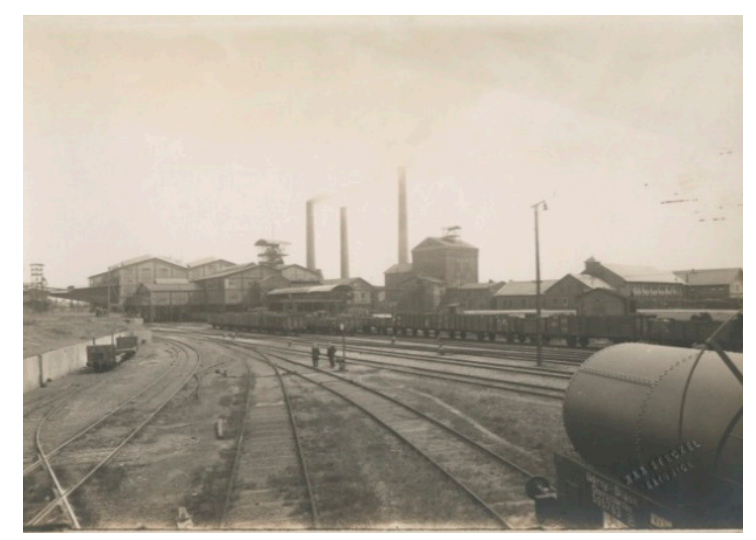

(a)

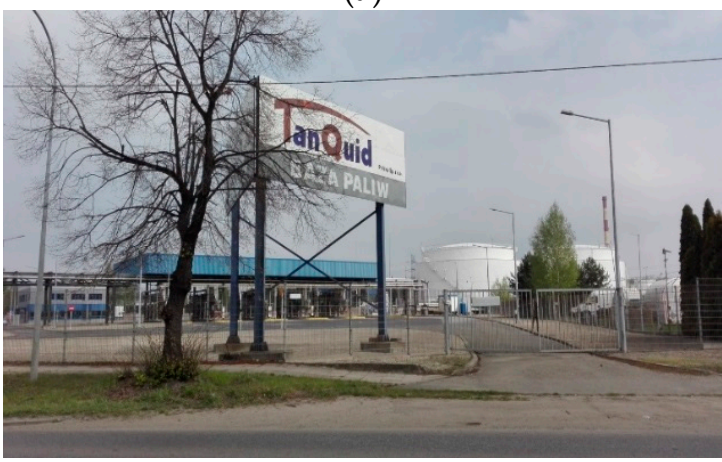

(c)

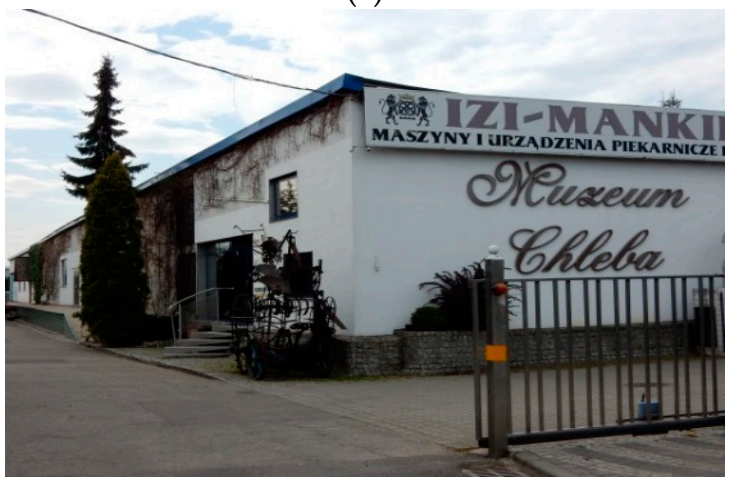

(e)

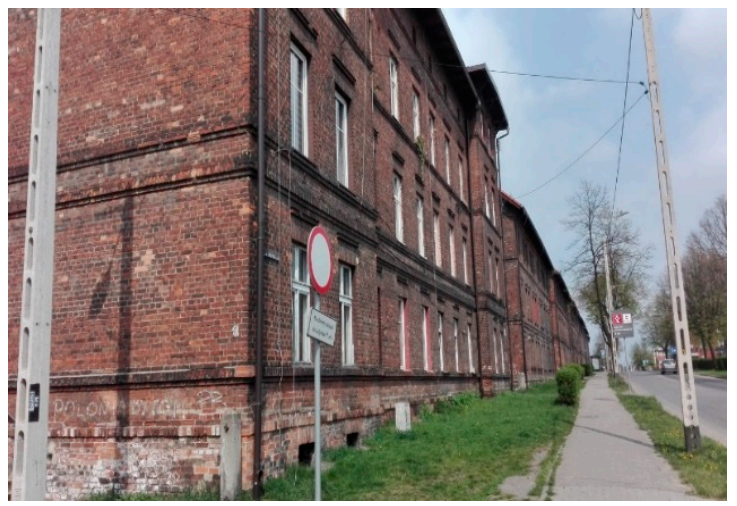

(b)

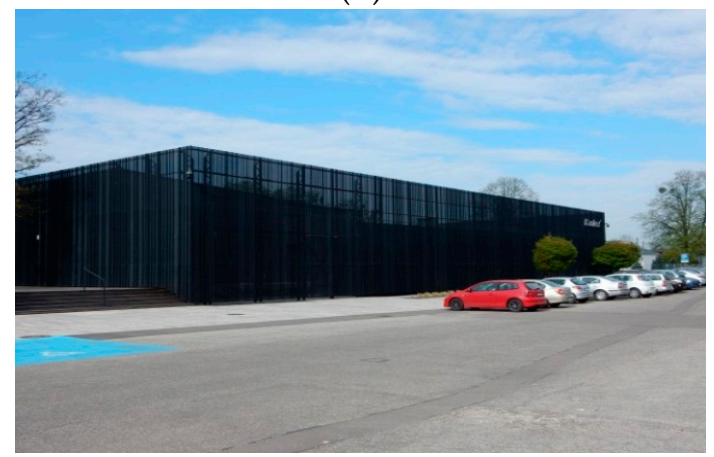

(d)

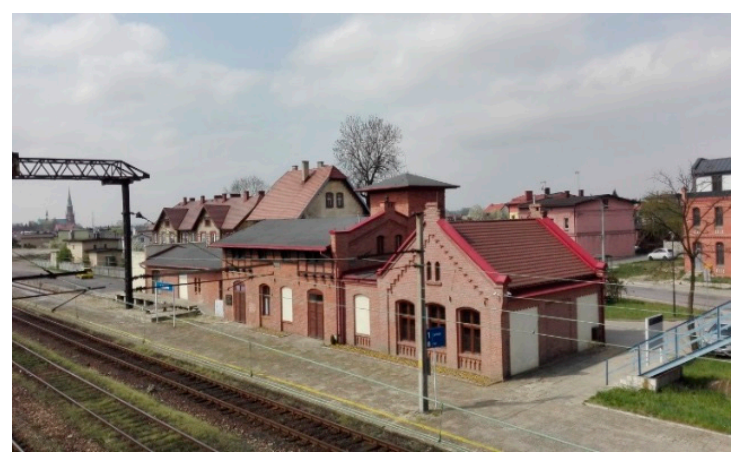

(f)

Figure 5. Radzionków (a) old photograph of the coal mine in Radzionków by Max Steckel; (b) mining estate in a town without a mine; (c) fuel base; (d) Kanlux Technology and Exhibition Centre; (e) Museum of Bread, School, and Trivia; and (f) Centre for Documentation of Upper Silesians' Deportation to the Soviet Union in 1945 located in the former railway station building (a: Max Steckel: from the collection of the Radzionków Town Hall, (b)-(f) illustration sourced by authors).

The need to develop other functions is visible in Ledziny if we also consider the issue of commuting. In 2016, 2608 people commuted to work outside town limits. Meanwhile, 608 persons travelled to work in Lędziny [72]. The noticeable share in commutes by Leedziny inhabitants to Tychy (1074), Katowice (399), or Bierun (386) may indicate a lack of jobs in services and manufacturing (Table 2). 
Table 1. Economic and social situation of Lędziny and Radzionków in 2017. Own elaboration on the base of $[57,58]$.

\begin{tabular}{|c|c|c|}
\hline Indicator/Feature & Lędziny & Radzionków \\
\hline \multicolumn{3}{|c|}{ Social Indicators } \\
\hline marriages per 1000 population & 5.5 & 5.1 \\
\hline divorces per 1000 population & 1.3 & 1.3 \\
\hline live births per 1000 population & 12.6 & 10.0 \\
\hline births to deaths ratio & 1.44 & 0.93 \\
\hline deaths per 1000 population & 8.9 & 10.9 \\
\hline pre-working age population (\%) & 19.3 & 16.5 \\
\hline working age population (\%) & 64.4 & 61.3 \\
\hline retirement age population (\%) & 16.3 & 22.2 \\
\hline natural increase & 57.0 & -16.0 \\
\hline migration balance & -12.0 & -33.0 \\
\hline Population dynamics 2000-2018 (\%) & 3.30 & -2.11 \\
\hline $\begin{array}{l}\text { Percentage of students in 20-24 year } \\
\text { age group (2012/2013) }\end{array}$ & 52.5 & 42.6 \\
\hline \multicolumn{3}{|c|}{ Economic Indicators } \\
\hline Employed per 1000 inhab.* & 337 & 208 \\
\hline $\begin{array}{c}\text { Employment structure (in \%) } \\
\text { agriculture } \\
\text { industry } \\
\text { services }\end{array}$ & $\begin{array}{c}0.2 \\
75.6 \\
24.2\end{array}$ & $\begin{array}{c}0.2 \\
47.2 \\
52.6\end{array}$ \\
\hline Unemployed per 1000 inhab.* (2018) & 10.8 & 17.9 \\
\hline $\begin{array}{l}\text { Unemployed per } 1000 \\
\text { employed (2018) }\end{array}$ & 31.0 & 83.4 \\
\hline $\begin{array}{l}\text { REGON-registered economic entities } \\
\text { per } 10,000 \text { inhab. (2018) }\end{array}$ & 749 & 1014 \\
\hline $\begin{array}{l}\text { Town budget income per inhab. } \\
\text { (in euros; National Bank of Poland } \\
\text { exchange rate from May 8, 2019) }\end{array}$ & 913 & 1037 \\
\hline
\end{tabular}

Explanations: * in economic entities employing over 9 employees.

Table 2. Commuting to work in Ledziny and Radzionków (2016). The most important interlinks. Own elaboration on the base of [72].

\begin{tabular}{cccc}
\hline \multicolumn{2}{c}{ Lędziny } & \multicolumn{2}{c}{ Radzionków } \\
\hline From & To & From & To \\
\hline Tychy (176) & Tychy (1074) & Bytom (778) & Bytom (657) \\
Mysłowice (136) & Katowice (399) & Tarnowskie Góry (304) & Katowice (456) \\
Chełm Ślaaski (72) & Bieruń (386) & Piekary Śląskie (265) & Tarnowskie Góry (420) \\
Imielin (68) & Mysłowice (225) & Świerklaniec (141) & Piekary Śląskie (265) \\
Bojszowy (37) & Bielsko-Biała (109) & Bobrowniki (53) & Gliwice (203) \\
\hline Total (608) & Total (2608) & Total (1937) & Total (2703) \\
\hline
\end{tabular}

The situation in the second of the analyzed towns, Radzionków, is significantly different. The closing of Radzionków's coal mine in the 1990s greatly contributed to deterioration of the labor market situation. An improvement occurred only in the 2000s. In postmining brownfields, 
a large fuel base, TanQuid (with a capacity of 135 thousand $\mathrm{m}^{3}$ of fuel) (Figure 5), and the large company Wtórmet were established. Also, the meat industry, 'HAM', and a renowned lighting manufacturer, Kanlux, made their way to functionally derelict land (brownfields and grayfields) (Figure 5). They joined the existing Ragor metalworks.

While reindustrialization caused a significant improvement in Radzionków's labor market situation, it did not yet testify to a new image of the town. This image was gradually built by location in the town of services that stood out in the region, but also in Poland, such as the Museum of Bread, School, and Trivia; Centre for Documentation of Upper Silesians' Deportation to the Soviet Union in 1945 (Figure 5); and the Silesian Botanical Garden. The policy of the town's authorities is definitely aimed at re-development of Radzionków's brownfields and grayfields (abandoned buildings of the secondary school and former railway station). An important achievement in the town's transformation towards the 4.0 model was the establishment of the Kanlux Tech Park Technological and Exhibition Centre in one of the most modern buildings in Poland (Figure 5). As Radzionków's mayor emphasizes, 'we not only want to develop the town, we want to shape it, and companies such as Kanlux and unique services with a supra-local significance are the priority for town authorities' [73]. With reference to the typology of functional changes in the Katowice conurbation's towns (Figure 2) as well as Ledziny's and Radzionków's place in this scheme, clear trends in the changes should be pointed out. While Ledziny is moving towards the category of a mining and service town, Radzionków is strengthening its potential towards the model of a service town with a significant role in industry 4.0. These changes are difficult in that, as [74] (p. 225) notes in his study of Polish towns, 'industry functioning in Poland only contributes to the building of enterprising and innovative communities that are the basis of a knowledge-based economy's development to a small extent'.

Lèdziny's and Radzionków's differing trajectories of economic growth since the end of the 20th century also have some impact on the demographic and social situation in the two towns to some degree. As seen in Table 1, all indicators of demographic growth are better in Lędziny than in Radzionków.

While different factors may contribute to this, a large role must have been played by phenomena related to the 'transformation trauma' experienced by Radzionków's residents. This is because mining towns are spaces where the functioning social norms are governed by common factors and by norms that are the heritage of mining culture. Mining culture refers to the specific nature of work-related activities and individual stages of mining, and it is characterized by religiosity bolstered by the threat to miners' lives and fears for miners' lives in their families. Local traditions and national or regional (Silesia, Silesians) identity are also at the forefront. Endurance, family, solidarity, and sense of duty are important. Other features that should be listed include isolationism of the mining community, its homogeneity, the specific way of spending free time, and social conventions outside the workplace [75].

As only Lędziny is still a mining town, in Radzionków these norms have become 'looser'. In Ledziny they are subject to social mixing via the commonality of global influences (globalization versus localization) and the elitism, egoism, self-creation, and change of attitude towards personal and family life that is apparent in studies.

As Warwick and Littlejohn [76] indicate, when the mining function is lost, problems that were so far muffled by the strength of mining functions and their social impact begin to surface. Primarily, it is revealed that the homogeneity ascribed to mining towns is often heterogeneity in the social and psychosocial layer. In a mining town, like in a small agricultural and rural community, any differences, individualism, and people's internal needs are regulated by the social dimension, limited by taboos, and socially contested. Nawrocki [55] writes about ceasing reproduction of social relationships and, in 2004, of the mining microcosms of mining settlements. Mrozek [77] draws attention to the disintegration of the bond that ultimately transforms a local community into a local collective. These phenomena as a whole have been presented with respect to Radzionków by Klekotko [78] in a sociological study of the town. 
An important accent in shaping the small mining town identity of Lędziny and Radzionków was attaining independent self-governance. There was a great need for secession of these two towns from Tychy and Bytom, dictated by various factors such as social homogeneity (some differences versus the large town they seceded from), distance, peripherization, and the need to make independent developmental decisions. An important role in the process of achieving a small mining town identity was played by grassroots initiatives. Among these, the activities of Radzionkowskie Stowarszyszenie Społeczno-Kulturalne (Radzionków Social and Cultural Association) turned out to be crucial. Today's perspective accents that gaining independence was the only correct course of development. All the more important for Ledziny because in 2002 the town became one of the seats of Bierun-Ledziny county, taking on additional administrative functions [79].

\section{Towards a Functional Model of a Small (Post)Mining Town}

Different development trajectories of small towns with mining and industrial origins located in the Katowice conurbation indicate that there are many factors shaping the socio-economical changes under study. When attempting to find patterns, however, it should be noted that the possibilities of change are largely determined by the existence or closure of mines or industrial plants that lie at the origins of a given town. In mining towns where a coal mine still operates, such as Ledziny, there exists a specific buffer of economic security. Differentiation of the economic base is expected; nevertheless, lack of successes in this area is not a serious threat to the town. The mine is a stabilizer, particularly when its existence in the coming decades is assured. The coal mining-based development model of a small town, therefore, creates a specific relationship in the economy, as a result of which the supplementary function is most often played by a different industrial activity (Figure 6). Examples of towns in the Katowice conurbation indicate that these are most frequently small and medium-sized manufacturing companies that have usually been developing since the socialist period. Meanwhile, well-accessible towns have the opportunity to expand logistics, which has been booming in the region since 2013 [80]. Paradoxically, the coal-based model of development of traditional industry visibly fosters (in Poland) demographic and social development (Table 1).

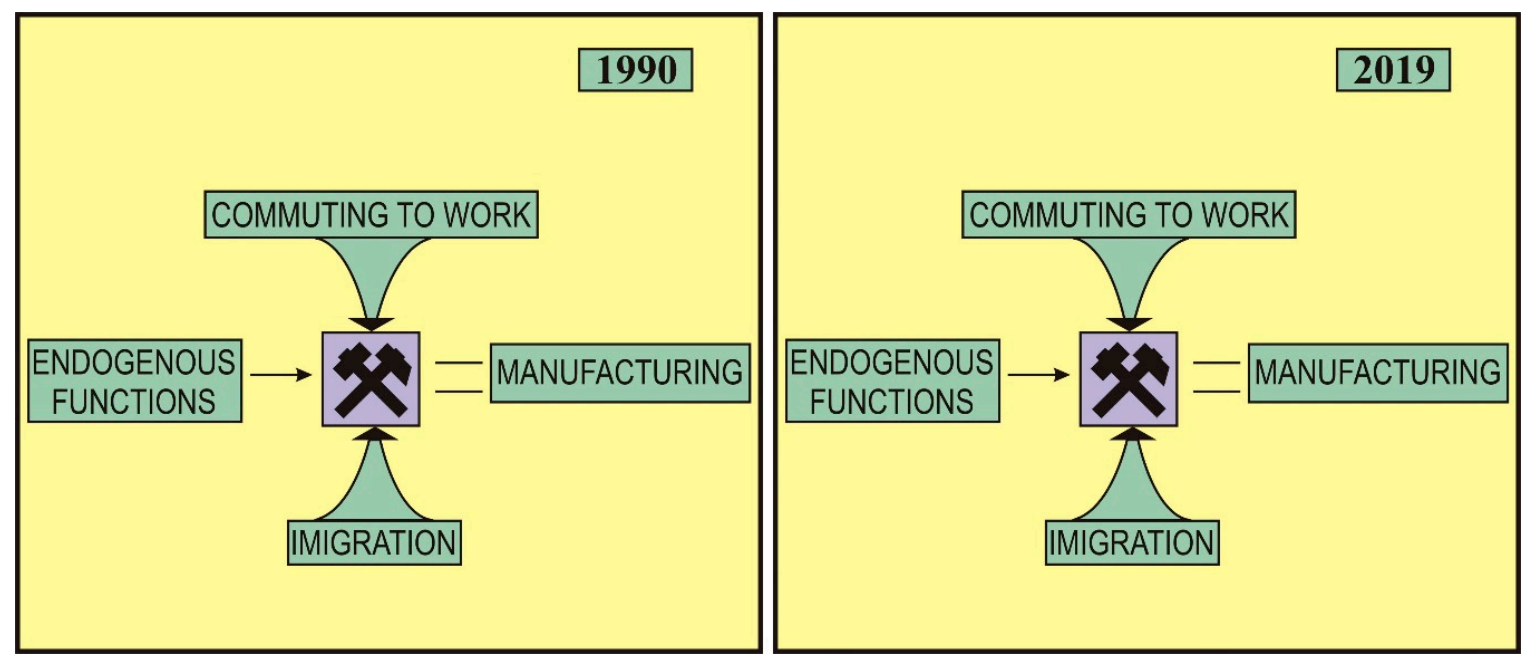

Figure 6. Socio-economic model of the development of a small mining town with continuing coal mining operations (illustration sourced by authors).

The socio-economic situation in a town in which a mine closes is visibly different from the model presented above. The loss of the key economic entity previously providing labor market stability and strengthening the town's budget causes a state of 'socio-economic trauma' as a result of 'transformation shock'. Many (post)mining landscape elements remain in the town space, but the driving force powering this specific local system of relationships is missing [81]. It is recognized that there are two 
possible reactions to transformation shock: passivity and activity. In the case of regions such as the Katowice conurbation, the proximity of large, richer towns (commuting) may be conducive to passivity. Nevertheless, from a long-term perspective it may have very negative consequences, which are partially visible in some towns in the region (e.g., city of Świetochłowice). By far the most common model of reaction to 'transformation shock' is an active reconstruction of a town's socio-economic image. The direction of this transformation and ambitions of local government leaders are, however, limited by determinants such as competition from towns in the polycentric urban region, competition from larger urban centers that have traditions of developing the functions also expected of a small postindustrial town, loss of previous embeddedness, lack of available space, accessibility in terms of transport, social capital, the town's image, and environmental problems. As a whole, these elements are visible in different configurations and different intensities in the development paths of small postindustrial towns in the Katowice conurbation. We present the effects of the relationships and influences, which is described as a structural and gravitational model (Figure 7). In it we indicate the possibilities for rebuilding the economic potential of a small post-mining town, taking into account the current situation of the Katowice conurbation. The case of Radzionków also fits this model, as its transformation covers three out of four of the areas distinguished, and the economic base and number of businesses or institutions representing the indicated economic sector falls with the increase in distance from the field symbolized by upside-down mining tools. This is a natural trend in the capacity for structural and systemic transformation, even in large post-mining and postindustrial towns of the Katowice conurbation. In small mining towns this is additionally connected to loss of social and organizational energy used to search for new urban functions, which not infrequently have to be shaped within an 'in cruda radice' model. Socio-economic difficulties in securing new economic activities are compounded by the effects of loss of embeddedness and visible social mismatch.
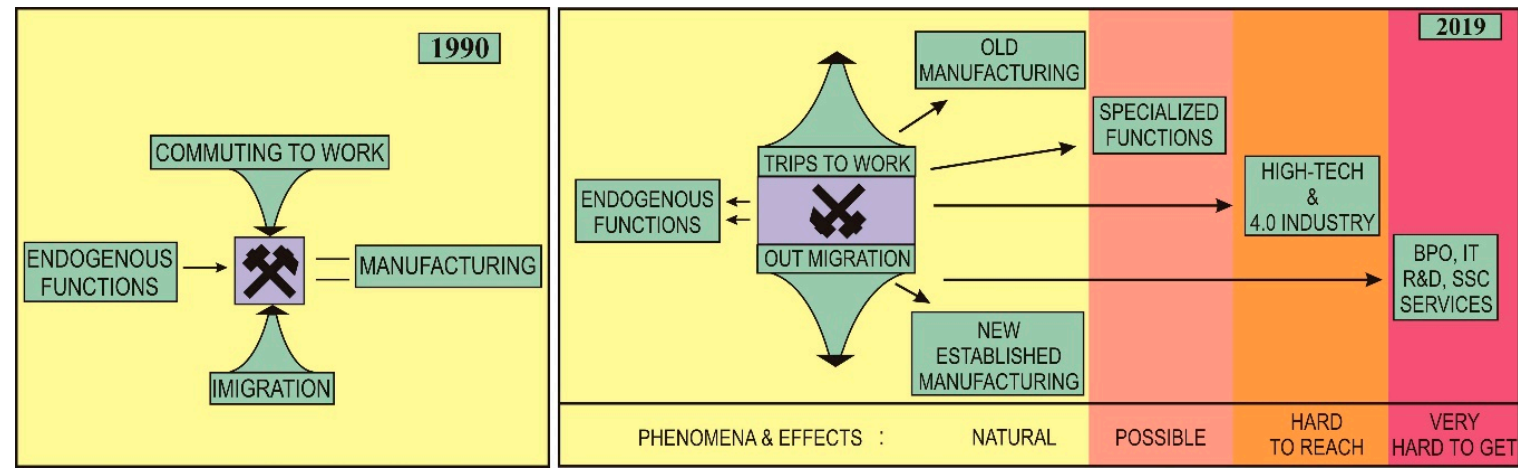

Figure 7. Socio-economic model of development of a small mining town where coal mines have been closed (illustration sourced by authors).

The social and demographic costs of economic transformation based on the above model are, despite visible economic successes, marked by a noticeable fall in inhabitant numbers. Nonetheless, in smaller towns in the Katowice region, it is still incomparable to losses experienced by medium-sized and large cities [52,82].

\section{Discussion}

The functional transformations of towns (also small ones) in the Katowice conurbation after the political and economic transformation of the 1990s are shaped according to several already acknowledged patterns:

- Gwosdz [83] distinguished six different models of path dependence-partly as a consequence of reaction to the 'shock of transformation' (positive-self-reinforcing, positive-reactive, positive-other, negative-self-enforcing, negative-reactive, and negative-other); 
- different rates of population changes (1990-2018)—while cities such as Bytom, Katowice and Sosnowiec lost more than $20 \%$ of the population during this period, some towns (Imielin, Mikołów) have even recorded a small increase; and

- $\quad$ in the case of small towns, the 'David against Goliath' phenomenon (localization of the first zones of the Katowice Special Economic Zone in bigger towns, competition about specialized function between the bigger and the medium size towns, and also between the medium size towns and the small towns).

Transformations in this region are also a good starting point for broader discussion. First, about the key goal a large part of local governments: knowledge-based economy or industry 4.0 should be further discussed. Strategia Województwa Ślaskiego (Strategy of the Silesian province) and Analiza potencjału rozwojowego ... (Analysis of potential for development...) [84,85], the creative industries in the Silesian province, require further development, which is related to their, as of yet, insufficient potential, particularly outside the main town of Katowice. These documents also indicate a relatively weak grounding of these activities in small mining and postindustrial towns.

Second, at this point it is worth examining whether the region in question and its towns are a good example of concepts mentioned in the Introduction that indicate the multiaspect marginalization of selected urban centers and areas.

Having analyzed the previous economic development of the Katowice conurbation, we claim that development of small postindustrial towns towards a residential model with a distinct industry 4.0 function (Figure 2) is very difficult here, and probably unattainable in the near future. We highlight the key to this problem in the preceding section, indicating the positive changes in Radzionków as an example. Apart from the abovementioned economic and geographical factors, issues of strong interurban competition and the distance of research and academic centers from Radzionków come to the fore (20-30 km of brain drain, the needs of some young people to live outside of Radzionków as small town (Table 3). The scale of these challenges in small postmining towns, which have not yet completely left behind post-transformation trauma, will always be greater than in larger towns. Also, the phenomenon of inadequateness of regional support, which has been well demonstrated by Beekmans et al. [86] does not help in this. Factors fostering activation in such towns are creative local governments and endogenous initiatives often based on 'local patriotism' with respect to location or relocation of companies [87]. Despite many difficulties, it is not impossible for industry 4.0 and creative companies to take root in a small mining town, as for example Kanlux's technological center in Radzionków shows. The company's modern center or the high-culture and specialized leisure facilities developed are, nevertheless, still located in a transindustrial economic landscape, in which we also find large fuel tanks belonging to one of the largest logistics companies of this type in southern Poland, modern meat establishment buildings, and traditional mine shafts in the city of Bytom neighboring Radzionków. These differences are also visible in the town's social space [78]. While the social aspect of the town has not been homogeneous for a long time, it is still hard to call it a postindustrial community. This is a specific combination in which the heritage of traditional culture, social norms based on a hard-working ethic, religiosity, and the creation of the family as the highest value are confronted with demographic and social phenomena described in the concept of the so-called second demographic transition, the effects of globalization, high mobility, and growing individualization of residents' needs and behaviors.

The examples of Radzionków, but also of Lędziny as highlighted in this paper, are also a good starting point for attempts to answer the question of whether small mining towns should be treated as insignificant places [43]. However, here we should ask: insignificant to whom? They are important and significant for the residents themselves, of course. They are also important-from other perspectives-to inhabitants of the region, and even the country. In Leedziny, where around $0.05 \%$ of Poland's population lives, around 5\% of the most important fuel (coal mine) used in the Polish economy is produced. The share of hard coal in the production of electricity in Poland in 2018 was $49.3 \%$ [88]. The town is also an important center for commuting, from counties even up to tens of 
kilometers away. Its importance may also be considered in terms of the wish to live there and continuity and stability of social structures. The paradox is that, in this respect, the mining town of Ledziny has overtaken a large majority of clearly depopulating Polish resorts towns [89]. For example, in the years 2008-2018 (Table 4), small resort towns recorded a total loss of population $-3.8 \%$, and depopulation took place in all 14 such centers. During the same period, all seven small Polish mining towns showed population growth of $0.7 \%$ (population growth in the five small mining towns only in Silesian province was $1.6 \%$.) $[90,91]$.

Table 3. Survey of Radzionków residents regarding the realities of life in 2013. Selected issues.

\begin{tabular}{ccccc}
\hline & \multicolumn{3}{c}{ Answer By } \\
\cline { 2 - 5 } Issue & Paper Questionnaire & $\begin{array}{c}\text { Computer-Assisted Telephone } \\
\text { Interviewing (CATI) }\end{array}$ \\
\cline { 2 - 5 } & Number & $\%$ & Number & \% \\
\hline $\begin{array}{c}\text { I work in this town and I am happy } \\
\text { with the place of life }\end{array}$ & 54 & 20.6 & 27 & 9.2 \\
\hline $\begin{array}{c}\text { Radzionków is a place where there } \\
\text { are no jobs }\end{array}$ & 94 & 35.9 & 115 & 39.4 \\
\hline $\begin{array}{c}\text { This town is a place where there is no } \\
\text { chance to make career }\end{array}$ & 64 & 24.4 & 88 & 27.7 \\
\hline $\begin{array}{c}\text { This town is a place where salaries are } \\
\text { too small }\end{array}$ & 59 & 22.5 & 37 & 50.5 \\
\hline $\begin{array}{c}\text { There is not enough work for young } \\
\text { people in Radzionków. }\end{array}$ & 175 & 66.8 & 147 & 27 \\
\hline
\end{tabular}

Table 4. Dynamics of population in small mining and resort towns in Poland, 2008-2018. Own elaboration.

\begin{tabular}{ccccc}
\hline Type of Small Towns & Number of Towns & $\mathbf{2 0 0 8}$ & $\mathbf{2 0 1 8}$ & Dynamics of Population in \% \\
\hline Mining small towns & 7 & 118,528 & 119,303 & 0.7 \\
\hline Resort small towns & 14 & 118,932 & 114,406 & -3.8 \\
\hline
\end{tabular}

Resorts are important to all inhabitants of Poland and also to the foreigners who visit them. In most countries, the importance of resort towns is actually placed in socially and economically prominent areas. The 'significance' policy in mining towns is also visible from the perspective of the strengthening of mining functions by Poland's current government [92] and the expansiveness of the mining milieu itself, which in Ledziny is in sharp conflict with the local authorities and residents of the neighboring Imielin. According to residents, mining activity will impact damage to residential and municipal buildings as well as transport infrastructure. There were 3166 flats in Imielin in 2017 [93,94]. The conflict concerning access to coal seams under Imielin has at least a regional dimension. The escalation of this conflict, which concerns miners keeping their jobs and preserving the current state of housing and infrastructure in suburban Imielin, is also a symbolical question about the importance of more general concepts: economic livelihood (Ledziny) and the right to inviolability of property (Imielin). Because the conflict is mounting, the 'significance' of these two small towns will also have a symbolic importance in the broader discourse about social and environmental costs of the energy production in Poland's future.

Nevertheless, we should remember that the labels of 'functional unnecessariness' primarily refer to towns that lost their previous economic base and experienced urban decline. If we apply the description of these labels and the 24-point definition of 'functional unnecessariness' [44] (p. 157), many towns meet the criteria. It also pertains to large towns, and as Kantor-Pietraga states, 21 out of the 24 criteria are met by Bytom, the large town from which Radzionków separated in 1999. In addition to the benefits Radzionków gained after separating from Bytom, the secession also had a symbolical dimension 
as an 'escape' from such a negative identity. This is demonstrated by numerous comments and statements, not only on social networking portals [95-97], but also made in individual conversations by Radzionków residents, who are happy with how their town is managed, and residents of the eight-fold larger city of Bytom, who are understandably jealous of Radzionków's development. The described relation is also well visible in work commuting. The small postindustrial Radzionków attracts 778 residents of bigger postindustrial Bytom, while Bytom is a place of work for only 657 residents of Radzionków [72]. From the current perspective, Radzionków should be termed a significant small town on the conurbation's economic and cultural map. Acquaintance with cultural facilities and companies such as the mentioned Kanlux is definitely supra-regional.

Of course, not all of the Katowice conurbation's towns and, even less so, towns in other regions of Poland and Europe were able to find new prodevelopmental impulses. From a physicalist point of view, no new system of connections has formed in them on the basis of centrifugal forces with a supra-regional scope [51]. Nonetheless, the last 30 years of socio-economic transformation in the Katowice conurbation indicate that reindustrialization or development of exogenous services may take place at various times [50]. The concepts of 'insignificant' or 'functionally unnecessary' places should be used with respect to phenomena and processes contributing to urban decline over a longer, at least 15-20 year period. Temporary 'insignificance', meanwhile, is a natural stage following the loss of previous function, rank, and position by any town. From a social point of view, it can also relate to the period in which old embeddedness has not yet been replaced by new, relatively stable embeddedness.

\section{Conclusions}

The process of socio-economic transformation of mining regions varies. Despite many similarities, there are also many differences. This is the case for a large number of towns with mining origins located in a single urban region, such as the Katowice conurbation in Poland discussed in the paper. The term transindustrialization was recently proposed for these differences (structural, systemic, and temporal), presented in regional terms and based mainly on studies of large and medium-sized cities [50]. The studies conducted on socio-economic transformations of small (post)mining towns in the Katowice region confirm the conclusions of the paper cited above. In the Katowice conurbation, small towns vary with respect to their functions. Some, like Leedziny, still base their growth on coal mining, and other branches-while desirable - will, at least in coming years, have a secondary character. The development of Radzionków is progressing completely differently. The end of coal mining produced a strong response, with the objective of reindustrialization, also referring to the concept of industry 4.0 and development of modern supra-regional services. Between these two model examples of small towns in the Katowice region, several others function that can be called 'halfway' models. The most frequent among them are:

- towns in which mining has worse chances for further growth, and other functions have not yet emerged for various reasons;

- postindustrial towns in which coal mine closure did not cause positive reactions, like in Radzionków;

- towns that, following the fall of coal mining, placed their bets on the processing industry or logistics; and

- towns in which the residential function is key.

It should be noted that in the Katowice conurbation similar paths of development have also been selected by large and medium-sized towns. The whole of the indicated differences in functions raise questions about the region's future, particularly in the context of the very negative demographic phenomena occurring in it (rapid depopulation, population aging, and conspicuous outmigration). Another important question is what role industry 4.0 could play in the transformation. Considering the course of the region's socio-economic transformation up to now, it may be expected that functional changes will follow an already established path. The cost of economic transformation and the systematic 
displacement of traditional industry by new branches of industry and exogenous services will still be social transformation, and one of its effects will be 'adaptive depopulation'. This model is particularly visible in the case of small (post)mining towns in the Katowice conurbation. The challenge for local and regional policy will, thus, be deciding which solutions to select in order to stay close to the 'built to suit' adage tried and tested in the economy. Best practices also applied in small towns of the region should be useful in this case as well.

Author Contributions: R.K. identified the research gap, contributed to the verification of the results, and was a major contributor in writing the manuscript. I.K.-P. was a major contributor in developing robust analytical methods, interpreting the results, and editing and writing (social questions) the manuscript. F.K. wrote about economic questions, organized the data collection. All authors read and approved the final manuscript.

Funding: This research received no external funding.

Conflicts of Interest: The authors declare no conflict of interest.

\section{References}

1. Heffner, K.; Marszał, T. (Eds.) Problemy Rozwoju Małych Miast w Wymiarze Lokalnym i Regionalnym (Problems of Development of Small Towns on Local and Regional Dimension); Komitet Przestrzennego Zagospodarowania Kraju PAN: Warszawa, Poland, 2005.

2. Burdack, J.; Knappe, E. The development of small towns in central Europe and the Baltic states. Geog. Raksti 2007, 13, 35-45.

3. Vaishar, A.; Lipovská, Z.; Št'astná, M. Small Towns in Post-Mining Regions. In Post-Mining Regions in Central Europe Problems, Potentials, Possibilities; Wirth, P., Mali, B.Č., Fischer, W., Eds.; Oekom: München, Germany, 2012; pp. 153-167.

4. Town Small and Medium Sized Towns in Their Functional Territorial Context Applied Research 2013/1/23 Inception Report. Version 04/07/2012. Available online: https://www.espon.eu/sites/default/files/attachments/ TOWN_Inception_report_July_2012.pdf (accessed on 10 May 2019).

5. Servillo, L.; Atkinson, R.; Hamdouch, A. Small and Medium-Sized Towns in Europe: Conceptual, Methodological and Policy Issues. Tijd. Econ. Soc. Geogr. 2017. [CrossRef]

6. Kwiatek-Sołtys, A.; Wiedermann, K.; Mainet, H.; Edouard, J.C. The Role of Industry in Satellite Towns of Polish and French Metropolitan Areas-Case Study of Myślenice and Issoire. Prace Komisji Geografii Przemystu Polskiego Towarzystwa Geograficznego 2014, 25, 194-211.

7. Marszał, T. Funkcja Przemysłowa Małych Miast; Wydawnictwo Uniwersytetu Łódzkiego: Łódź, Poland, 2009.

8. Wirth, P.; Černič Mali, B.; Fischer, W. (Eds.) Post-Mining Regions in Central Europe Problems, Potentials, Possibilities; Oekom: München, Germany, 2012.

9. Wideramnn, K. The role of industry in the Labour market of small towns. Ann. Univ. Paedagog. Crac. Studia Geogr. 2015, 8, 67-79.

10. Bontje, M.; Burdack, J. Edge Cities, European-style: Examples from Paris and the Randstad. Cities 2005, 22, 317-330. [CrossRef]

11. Meijers, E.J.; Burger, M.J.; Hoogerbrugge, M.M. Borrowing size in networks of cities: City size, network connectivity and metropolitan functions in Europe. Pap. Reg. Sci. 2016, 95, 181-199. [CrossRef]

12. Malý, J. Small Towns in the Context of "Borrowed Size" and "Agglomeration Shadow" Debates: The Case of the South Moravian Region (Czech Republic). Eur. Countrys. 2016, 8, 333-350. [CrossRef]

13. Scott, A.J. Locational patterns and dynamics of industrial activity in the modern metropolis. Urban Stud. 1982, 19, 111-142. [CrossRef]

14. Meijers, E. Polycentric Urban Regions and the Quest for Synergy: Is a Network of Cities More than the Sum of the Parts? Urban Stud. 2005, 42, 765-782. [CrossRef]

15. Green, N. Functional Polycentricity: A Formal Definition in Terms of Social Network Analysis. Urban Stud. 2007, 44, 2077-2103. [CrossRef]

16. Drobniak, A.; Kolka, M.; Skowroński, M. Transition and Urban Economic Resilience in Poland's Post-industrial Cities: The Case of Katowice. Reg. Mag. 2012, 286, 13-15. [CrossRef] 
17. Waddington, D.; Parry, D. Managing industrial decline: The lessons of a decade of research on industrial contraction and regeneration in Britain and other EU coal producing countries. Min. Technol. 2003, 112, 47-56. [CrossRef]

18. Pipan, T. Neo-industrialization models and industrial culture of small towns. GeoScape 2018, 12, 10-16. [CrossRef]

19. Domański, B. Economic trajectory, path dependency and strategic intervention in an old industrial region: The case of Upper Silesia. In Recent Advances in Urban and Regional Studies; Domański, R., Ed.; Polish Academy of Sciences: Warsaw, Poland, 2003.

20. Fol, S.; Cunningham-Sabot, E. Urban Decline and Shrinking Cities: A Critical Assessment of Approaches to Urban Shrinkage. Ann. Géogra. 2010, 4, 359-383. [CrossRef]

21. Kunc, J.; Martinát, S.; Tonev, P.; Frantál, B. Destiny of urban brownfields: Spatial patterns and perceived consequences of post-socialistic deindustrialization. Transylv. Rev. Adm. Sci. 2014, 41, 109-128.

22. Bulmer, M.I.A. Sociological Models of the Mining Community. Sociol. Rev. 1975, 23, 61-92. [CrossRef]

23. Smith, B.E. Another Place Is Possible? Labor Geography, Spatial Dispossession, and Gendered Resistance in Central Appalachia. Ann. Assoc. Am. Geogr. 2015, 105, 567-582. [CrossRef]

24. Burrell, B. The role of coal-mining towns in social theory: Past, present and future. Glob. Discourse 2017, 7, 451-468. [CrossRef]

25. Short, J.R.; Benton, L.M.; Luce, W.B.; Walton, J. Reconstructing the Image of an Industrial City. Ann. Assoc. Am. Geogr. 1993, 83, 207-224. [CrossRef]

26. Arefi, M. Non-place and placelessness as narratives of loss: Rethinking the notion of place. J. Urban Des. 1999, 4, 179-193. [CrossRef]

27. While, A.; Eadson, W. Households in place: Socio-spatial (dis)advantage in energy-carbon restructuring. Eur. Plan. Stud. 2019, 27, 1626-1645. [CrossRef]

28. Ache, P. Citiesin Old Industrial Regions between Local Innovative Milieu and Urban Governance-Reflections on City Region Governance. Eur. Plan. Stud. 2000, 8, 693-709. [CrossRef]

29. Harfst, J.; Wirth, P. Structural Change in former mining regions: Problems, potentials and capacities in multi-level governance systems. Procedia-Soc. Behav. Sci. 2011, 14, 167-176. [CrossRef]

30. Marot, N.; Černič Mali, B. Using the Potentials of Post-Mining Regions-A Good Practice Overview of Central Europe. In Post-Mining Regions in Central Europe Problems, Potentials, Possibilities; Wirth, P., Mali, B.Č., Fischer, W., Eds.; Oekom: München, Germany, 2012; pp. 130-147.

31. Rink, D.; Couch, C.; Haase, A.; Krzysztofik, R.; Nadolu, B.; Rumpel, P. The governance of urban shrinkage in cities of post-socialist Europe: policies, strategies and actors. Urban Res and Pract. 2014, 7, 258-277. [CrossRef]

32. Sztando, A. Współczesne wyzwania państwowej polityki rozwoju lokalnego w świetle oczekiwań władz małych miast (Contemporary Challenges of the State's Local Development Policy in the Light of Expectations of the Authorities of Small Cities). Zeszyty Naukowe Uniwersytetu Ekonomicznego w Krakowie 2017, 961, 67-84. [CrossRef]

33. Klusáček, P.; Krej čí, P.; Kunc, J.; Martinát, S.; Nováková, E. The post-industrial 701 landscape in relation to local self-government in the Czech Republic. Morav. Geogr. Rep. 2011, 19, 8-28.

34. Rumpel, P.; Slach, O. Governance of Shrinkage of the City of Ostrava; European Science and Art Publishing: Praha, Czech Republic, 2012.

35. Bosák, V.; Nováček, A.; Slach, O. Industrial culture as an asset, barrier and creative challenge for restructuring of old industrial cities: Case study of Ostrava (Czechia). GeoScape 2018, 12, 52-64. [CrossRef]

36. Danilin, O. On the way to decline: The development of the Donbass coal-mining industry from the 1950s to the 1980s. Min. Technol. 2002, 111, 161-171. [CrossRef]

37. Amosha, O.; Lyakh, O.; Soldak, M.; Cherevatskyi, D. Institutional determinants of implementation of the smart specialisation concept: Case for old industrial coal-mining regions in Ukraine. J. Eur. Econ. 2018, 17, 305-332.

38. Blotevogel, H.H. The Rhine-Ruhr metropolitan region: Reality and discourse. Eur. Plan. Stud. 1998, 6, 395-410. [CrossRef]

39. Wehling, H.W. Montanindustrielle Kulturlandschaft Ruhrgebiet. Raumzeitliche Entwicklung im regionalen und europäischen Kontext. Siedlungsforschung 1998, 16, 167-189. Available online: https://www. kulturlandschaft.org/publikationen/siedlungsforschung/sf16-1998.pdf (accessed on 10 May 2019). 
40. Van Houtum, H.; Lagendijk, A. Contextualizing Regional Identity and Imagination in the Construction of Polycentric Urban Regions: The Cases of the Ruhr Area and the Basque Country. Urban Stud. 2001, 38, 747-767. [CrossRef]

41. Schwarze-Rodrian, M. Ruhr Region Case Study. Remaking Postindustrial Cities. Lessons from North America and Europe; Carter, D.K., Ed.; Routledge: New York, NY, USA; Abingdon, UK, 2016; pp. 187-209.

42. Phepls, N.A.; Ozawa, T. Contrasts in agglomeration: Proto-industrial, industrial and post-industrial form compared. Prog. Hum. Geogr. 2003, 27, 583-604.

43. Rodríguez-Pose, A. The revenge of the places that don't matter (and what to do about it). Camb. J. Reg. Econ. Soc. 2018, 11, 189-209. [CrossRef]

44. Kantor-Pietraga, I. Systematyka procesu depopulacji miast na obszarze Polski od XIX do XXI wieku; Wydawnictwo Uniwersytetu Śląskiego: Katowice, Poland, 2014.

45. Malmberg, A.; Maskell, P. Toward an explanation of regional specialization and industry agglomeration. Eur. Plan. Stud. 1997, 5, 25-41. [CrossRef]

46. Grabher, G. The Weakness of Strong Ties: The Lock-in of Regional Development in the Ruhr Area. In The Embedded Firm: On the Socioeconomics of Industrial Networks; Routledge: London, UK, 1993; pp. 255-277.

47. Gwosdz, K.; Sobala-Gwosdz, A. Struktura funkcjonalna i powiązania miast konurbacji katowickiej po dwóch dekadach restrukturyzacji. Prz. Geogr. 2012, 84, 483-507. [CrossRef]

48. Gwosdz, K. Pomiędzy Stara a Nowa Ścieżka Rozwojowa. Mechanizmy Ewolucji Struktury Gospodarczej i Przestrzennej Region Tradycyjnego Przemystu na Przykładzie Konurbacji Katowickiej po 1989 Roku; IGiGP Uniwersytet Jagielloński: Kraków, Poland, 2014.

49. Tkocz, M. Restrukturyzacja Przemystu Regionu Tradycyjnego; Uniwersytet Ślasski: Katowice, Poland, 2001.

50. Krzysztofik, R.; Tkocz, M.; Spórna, T.; Kantor-Pietraga, I. Some dilemmas of post-industrialism in a region of traditional industry: The case of the Katowice conurbation, Poland. Morav. Geogr. Rep. 2016, 24, $42-54$. [CrossRef]

51. Krzysztofik, R. Geneza aglomeracji miast na obszarze Polski; Wydawnictwo Uniwersytetu Ślaskiego: Katowice, Poland, 2014.

52. Sitek, S.; Runge, J.; Kłosowski, F.; Runge, A.; Petryszyn, J.; Pytel, S.; Spórna, T.; Kurpanik, M.; Zuzańska-Żyśko, E. Społeczno-gospodarcze i przestrzenne kierunki zmian regionalnego oraz lokalnych rynków pracy województwa ślaskiego; WNoZ UŚ: Sosnowiec, Poland, 2013.

53. Kolasińska, M.; Konior, P.; Miśka, J.; Noga, J.; Żelazny, R.; Hantke, W. (Eds.) Regionalne mierniki rozwoju. In Moduł Gospodarczy. Część II, Urząd Marszałkowski Województwa Ślaskiego; Wydział Rozwoju Regionalnego, Regionalne Centrum Analiz i Planowania Strategicznego: Katowice, Poland, 2015; pp. 151-204.

54. Nawrocki, T. Trwanie i Zmiana Lokalnej Społeczności Górniczej na Górnym Śląsku; Wydawnictwo Uniwersytetu Śląskiego: Katowice, Poland, 2006.

55. Szmytkie, R.; Krzysztofik, R. The processes of incorporation and secession of urban and suburban municipalities: The case of Poland. Nor. Geogr. Tidsskr.-Nor. J. Geogr. 2019, 73, 110-127. [CrossRef]

56. Rocznik Statystyczny Województwa Ślaskiego (Statistical Yearbook of the Ślaskie Voivodship); Urząd Statystyczny w Katowicach (Statistical Office in Katowice): Katowice, Poland, 2001.

57. Województwo Ślaskie. Podregiony, Powiaty, Gminy (Ślaskie Voivodship. Subregions, Powiats, Gminas); Urząd Statystyczny w Katowicach (Statistical Office in Katowice): Katowice, Poland, 2018.

58. Lux, G. The institutional conditions of reindustrialization in post-crisis Central Europe. J. Econ. Manag. 2015, 19, 16-33.

59. Polska Grupa Górnicza, S.A. Available online: www.PGG.pl (accessed on 1 May 2019).

60. Jastrzębska Spółka Węglowa, S.A. Available online: www.JSW.pl (accessed on 1 May 2019).

61. Domański, B.; Guzik, R.; Gwosdz, K. The New International Division of Labour and the Changing Role of the Periphery. The Case of the Polish Automotive Industry. In Globalising Worlds and New Economic Configurations; Tamásy, C., Taylor, M., Eds.; Ashgate: Aldershot, UK, 2008; pp. 85-100.

62. Rachwał, T.; Wiedermann, K. Multiplier effects in regional development. The case of the motor vehicle industry in Silesian Voivodeship (Poland). Quaest. Geogr. 2008, 27B, 67-80.

63. Katowicka Specjalna Strefa Ekonomiczna. Available online: http://www.ksse.com.pl/o-ksse-1 (accessed on 10 May 2019). 
64. Kłosowski, F. Ćwierćwiecze procesu restrukturyzacji gospodarki regionu śląskiego (województwa śląskiego)—próba oceny. In Restrukturyzacja regionów ostrawskiego i katowickiego jako możliwość wspótpracy czesko-polskiej; Zawodna, M., Ed.; University of Ostrava: Ostrava, Czech Republic, 2016; pp. 53-70.

65. Klasik, A. Przemysły kreatywne oparte na nauce i kulturze. In Kreatywne Miasto-Kreatywna Aglomeracja; Klasik, A., Ed.; Prace Naukowe/Akademia Ekonomiczna w Katowicach: Katowice, Poland, 2009; pp. 31-41.

66. Runge, A.; Kantor-Pietraga, I.; Runge, J.; Krzysztofik, R.; Dragan, W. Can Depopulation Create Urban Sustainability in Postindustrial Regions? A Case from Poland. Sustainability 2018, 10, 4633. [CrossRef]

67. Heder, A.; Tkocz, M. Zmiany demograficzne i funkcjonalne małych miast górniczych (na przykładzie Bierunia i Lędzin). Acta Geogr. Sil. 2011, 10, 11-20.

68. Zatrudnienie w Kopalni Ziemowit. Available online: https://pgg.pl/o-firmie/oddzialy/3zi (accessed on 12 May 2019).

69. Imielin: PGG Chce Fedrować. Mieszkańcy są Przeciwni. Jaką Decyzję Wyda Generalna Dyrekcja Ochrony Środowiska?. Available online: https://plus.dziennikzachodni.pl/imielin-pgg-chce-fedrowac-mieszkancysa-przeciwni-jaka-decyzje-wyda-generalna-dyrekcja-ochrony-srodowiska/ar/c3-14010263 (accessed on 30 April 2019).

70. Strategia Rozwoju Miasta Lędziny do Roku 2020. 2014. Available online: http://www.ledziny.pl/files/news/ aktualnosci/strategiaaktualizacja.pdf (accessed on 31 May 2019).

71. Przepływy Ludności Związane z Zatrudnieniem w 2016 r. Available online: https://poznan.stat.gov.pl/ osrodki/osrodek-statystyki-miast-1234/osrodek-statystyki-miast-1185/przeplywy-ludnosci-zwiazane-zzatrudnieniem-w-2016-r/ (accessed on 23 June 2019).

72. Tobor Gabriel. Interview. 9 May 2019.

73. Wiedermann, K. Wspótczesne Modele Uprzemysłowienia a Kształtowanie się Struktur Społecznych i Gospodarczych. Poziom Międzynarodowy, Regionalny, Lokalny; Wydawnictwo Naukowe Uniwersytetu Pedagogicznego w Krakowie: Kraków, Poland, 2016.

74. Tambor, J. Autostereotyp i stereotyp Ślazaka. Postscriptum Polonistyczne 2008, 1, 81-97.

75. Warwick, D.; Littlejohn, G. Coal, Capital and Culture; Taylor and Francis: London, UK, 1992.

76. Mrozek, W. Górnicy—Od grupy społecznej do kategorii zawodowej. In Eseje Socjologiczne; Jacher, W., Ed.; Uniwersytet Śląski: Katowice, Poland, 2001; pp. 9-27.

77. Klekotko, M. Rozwój po Ślasku. Procesy Kapitalizacji Kultury w Ślaskiej Społeczności Górniczej, Seria: Jagiellońskie Studia Socjologiczne; Wydawnictwo Uniwersytetu Jagiellońskiego: Kraków, Poland, 2012.

78. Łysko, A. Nasze Dziedzictwo; Starostwo Powiatowe Powiatu Bieruńsko—Lędzińskiego: Bieruń, Poland, 2005.

79. Krzysztofik, R.; Kantor-Pietraga, I.; Spórna, T.; Dragan, W.; Mihaylov, V. Beyond 'logistics sprawl' and 'logistics anti-sprawl'. Case of the Katowice region, Poland. Eur. Plan. Stud. 2019, 27, 1646-1660. [CrossRef]

80. Faull, M.L. Coal mining and the landscape of England, 1700 to the present day. Landsc. Hist. 2012, 30, 59-74. [CrossRef]

81. Runge, A. Rola Miast Średnich w Ksztattowaniu Systemu Osadniczego Polski; Wydawnictwo Uniwersytetu Śląskiego: Katowice, Poland, 2013.

82. Gwosdz, K. Koncepcja zależności od ścieżki (path dependence) w geografii społeczno-ekonomicznej. Prz. Geogr. 2004, 76, 433-456.

83. Strategia Rozwoju Województwa Ślaskiego. Ślasskie “2020+”; Urząd Marszałkowski Województwa Śląskiego: Katowice, Poland, 2013.

84. Analiza Potencjału Rozwojowego Funkcji Metropolitalnych Obszarów Aglomeracji Miejskich Województwa Śląskiego, Będących Ośrodkami Wzrostu gospodarczego Województwa Śląskiego w Kontekście Procesów Zachodzacych na Regionalnym Rynku Pracy—Sektor Usług Nowoczesnych—Raport Końcowy. 2012. Available online: https:/rcas.slaskie.pl/content/analiza-potencjalu-rozwojowego-funkcji-metropolitalnychobszarow-aglomeracji-miejskich-wojewodztwa-slaskiego-bedacych-osrodkami-wzrostu-gospodarczegowojewodztwa-slaskiego-w-kontekscie-procesow-zachodzacych-na-regionalnym-rynku-pracy---sektoruslug-nowocz (accessed on 19 June 2019).

85. Strategia Rozwoju Miasta Radzionków na Lata 2014-2025. 2014. Available online: http://www.bip. radzionkow.pl/?c=2363 (accessed on 18 June 2019).

86. Beekmans, J.; Ploegmakers, H.; Martens, K.; van der Krabben, E. Countering decline of industrial sites: Do local economic development policies target the neediest places? Urban Stud. 2015, 53, 3027-3047. [CrossRef] 
87. Marot, N. What is the most Suitable Self-governing Structure. A Case Study of Slovenian Post-mining town. In Development in Minor Cities: Institutions Matter; Sucháček, J., Petersen, J.J., Eds.; Department of Regional and Environmental Economics, Faculty of Economics, Ostrava, VŠB-Technical University of Ostrava: Ostrava, Czechia, 2010; pp. 127-147.

88. Transformacja Energetyczna w Polsce. Forum Energii. 2019. Available online: https://forum-energii.eu/pl/ analizy/transformacja-2019 (accessed on 19 June 2019).

89. Kantor-Pietraga, I.; Krzysztofik, R.; Runge, J. Kontekst geograficzny i funkcjonalny kurczenia się małych miast w Polsce Południowej. In Ewolucja funkcji małych miast w Polsce; Heffner, K., Halama, A., Eds.; Studia Ekonomiczne/Uniwersytet Ekonomiczny w Katowicach: Katowice, Poland, 2012; Volume 92, pp. 9-24.

90. Powierzchnia i Ludność w Przekroju Terytorialnym w 2008 r.; GUS: Warszawa, Poland, 2008.

91. Powierzchnia i Ludność w Przekroju Terytorialnym w 2018 r.; GUS: Warszawa, Poland, 2018.

92. Beata Szydło: Polskie Górnictwo ma Przed Sobą Przyszłość. Available online: https://gornictwo.wnp.pl/ beata-szydlo-polskie-gornictwo-ma-przed-soba-przyszlosc,332443_1_0_0.html (accessed on 10 May 2019).

93. Gmina Miejska Imielin. Powiat Bieruńsko-Lędziński. Statystyczne Vademecum Samorząowca; Urzą Statystyczny w Katowicach: Katowice, Poland, 2018. Available online: https://katowice.stat.gov.pl/ vademecum/vademecum_slaskie/portrety_gmin/powiat_bierunsko-ledzinski/gmina_imielin.pdf (accessed on 20 June 2019).

94. Czoik, T. Związowiec do Mieszkańca Imielina, Który Protestuje Przeciw Budowie Kopalni: "Będziesz wisiat"; Gazeta Wyborcza w Katowicach: Katowice, Poland, 2019; Available online: http://katowice.wyborcza.pl/ katowice/7,35063,24753405,zwiazkowiec-do-mieszkanca-imielina-ktory-protestuje-przeciw.html (accessed on 20 June 2019).

95. Miasto Radzionków-Strona Główna. Facebook. Available online: www.facebook.com/radzionkow (accessed on 8 May 2019).

96. Bytomski.pl: Bytom-Gazeta i Portal Miejski. Available online: www.bytomski.pl (accessed on 9 May 2019).

97. Życie Bytomskie. Available online: www.zyciebytomskie.pl (accessed on 8 May 2019).

(C) 2019 by the authors. Licensee MDPI, Basel, Switzerland. This article is an open access article distributed under the terms and conditions of the Creative Commons Attribution (CC BY) license (http://creativecommons.org/licenses/by/4.0/). 